\title{
Pengaruh Pengalaman Kerja, Kompetensi dan Integritas Auditor Terhadap Kualitas Hasil Audit
}

\author{
Made Cahyadi Wiranata Kusuma ${ }^{1}$ \\ Fakultas Ekonomi dan Bisnis \\ Universitas Udayana, Indonesia
}

\author{
I Gst Ayu Eka Damayanthi² \\ Fakultas Ekonomi dan Bisnis \\ Universitas Udayana, Indonesia
}

\begin{abstract}
ABSTRAK
Masyarakat Ekonomi Asean (MEA) menjadi salah satu pemicu perkembangan perekonomian di Indonesia. Perusahaan perusahaan di Indonesia semakin banyak yang go public. Sehingga sangat diperlukannya laporan keuangan yang jujur, wajar dan tidak menyesatkan pemakainya. Salah satu kebijakan yang dapat ditempuh dengan melakukan pemeriksaan laporan keuangan oleh auditor. Penelitian ini bertujuan untuk mengetahui pengaruh pengalaman kerja, kompetensi, dan integritas auditor pada kualitas hasil audit. Objek penelitian adalah kualitas hasil audit pada KAP di Provinsi Bali. Teknik penentuan sampel yang digunakan dalam penelitian ini adalah purposive sampling yaitu teknik penentuan sampel dengan pertimbangan tertentu. Sampel 65 auditor dengan jumlah 42 pernyataan. Berdasarkan hasil analisis penelitian diperoleh Pengalaman Kerja memiliki pengaruh negatif pada Kualitas Hasil Audit, Kompetensi memiliki pengaruh positif pada Kualitas Hasil Audit, dan Integritas auditor memiliki pengaruh positif pada Kualitas Hasil Audit.
\end{abstract}

Kata Kunci: Pengalaman Kerja; Kompetensi; dan Integritas Auditor.

\section{Effect of Work Experience, Competence and Auditor Integrity on the Quality of Audit Results}

\begin{abstract}
The Asean Economic Community (MEA) is one of the triggers of economic development in Indonesia. Many companies in Indonesia are going public. So it is necessary for financial statements that are honest, reasonable and do not mislead the wearer. One of the policies that can be taken is by auditing the financial statements by the auditor. This study aims to determine the effect of work experience, competence, and auditor integrity on the audit quality. The object of the research is the quality of the audit results in KAP in Bali. The sampling technique was purposive sampling, namely the technique of determining samples with certain considerations. The sample was 65 auditors with 42 statements. Based on the results of the analysis, Work Experience has a negative influence on the Audit Quality, Competence has a positive influence on the Audit Quality, and auditor Integrity has a positive influence on the Audit Quality.
\end{abstract}

Keywords: Work Experience; Competence; and Auditor Integrity.

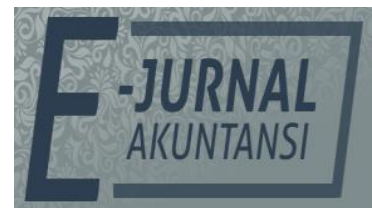

e-ISSN 2302-8556

Vol. 30 No. 9

Denpasar, September 2020 Hal. 2403-2416

DOI:

10.24843/EJA.2020.v30.i09.p18

PENGUTIPAN:

Kusuma, M. C. W. \&

Damayanthi, I G. A. E.

(2020). Pengaruh

Pengalaman Kerja, Kompetensi dan Integritas Auditor Terhadap Kualitas Hasil Audit. E-Jurnal Akuntansi, 30(9), 2403-2416

RIWAYAT ARTIKEL: Artikel Masuk: 1 Juli 2019 Artikel Diterima: 16 Juli 2019

Artikel dapat diakses : https://ojs.unud.ac.id/index.php/Akuntansi/index 


\section{PENDAHULUAN}

Saat ini Indonesia sedang menghadapi Masyarakat Ekonomi ASEAN (MEA). Pembentukan MEA yang pada awalnya diprediksi akan dimulai pada tahun 2020 pada akhirnya Negara-negara anggota ASEAN sepakat untuk mempercepat pembentukan MEA menjadi tahun 2015. Hal itu menggambarkan tekad ASEAN untuk segera meningkatkan pertumbuhan ekonomi dan daya saing antar sesama Negara anggota ASEAN untuk menghadapi persaingan global.

Masyarakat Ekonomi ASEAN merupakan satu pasar tunggal di kawasan Asia Tenggara yang bertujuan untuk meningkatkan investasi asing di kawasan Asia Tenggara. Terdapat lima hal yang tidak boleh dibatasi peredarannya diseluruh Negara ASEAN termasuk Indonesia, yaitu arus barang, arus jasa, arus modal, arus investasi dan arus tenaga kerja terlatih. Dalam situasi ini yang dimaksud adalah daya saing, karena apabila tidak disiapkan maka ada kemungkinan masyarakat kita hanya sebagai penonton dan negeri ini akan menjadi pasar dari produk asing (Feney, 2017).

Berkaitan dengan adanya Masyarakat Ekonomi ASEAN (MEA), perkembangan perekonomian di Indonesia semakin pesat hingga saat ini, sehingga memicu semakin banyaknya pertumbuhan perusahaan yang go public. Persaingan antar pelaku bisnis yang semakin meningkat tidak dapat dihindari mengingat di Indonesia juga sedang menghadapi MEA, secara otomatis ruang lingkup persaingan antar pelaku bisnis semakin luas. Berbagai macam usaha dilakukan agar perusahaan dapat bertahan didalam persaingan didunia bisnis, salah satunya dengan menyediakan laporan keuangan yang jujur, wajar dan tidak menyesatkan pemakainya dalam pengambilan keputusan (Pratistha \& Widhiyani, 2014). Salah satu kebijakan yang ditempuh oleh pihak perusahaan adalah dengan melakukan pemeriksaan laporan keuangan perusahaan oleh pihak ketiga yaitu auditor sebagai pihak yang dianggap independen. Karena salah satu persyaratan untuk memperkuat keabsahan dari suatu laporan keuangan perusahaan yang go public harus mempunyai opini dari akuntan publik (Hassink \& Russo, 2010).

Seorang auditor dalam melaksanakan audit atas laporan keuangan tidak semata-mata bekerja untuk kepentingan kliennya, melainkan juga untuk kepentingan pihak lain yang mempunyai kepentingan atas laporan keuangan yang diaudit. Menurut Sukrisno (2000:2), auditing memberikan nilai tambah bagi laporan keuangan perusahaan, karena akuntan publik sebagai pihak yang ahli dan independen pada akhir pemeriksaannya akan memberikan pendapat mengenai kewajaran posisi keuangan, hasil usaha, perubahan ekuitas dan laporan arus kas suatu perusahaan. Pentingnya menggunakan jasa auditor independen untuk memeriksa laporan keuangan perusahaan, dapat meyakinkan pihak luar bahwa laporan keuangan yang disajikan manajemen perusahaan berisi informasi yang dapat dipercaya melalui pendapat yang diberikan dalam laporan auditor (D'Arcy, Haugen, \& Mattson, 2005).

Menurut Statement Of Financial Accounting Concept (SFAC) No. 2, bahwa relevasi dan reabilitas adalah dua kualitas utama yang menjadikan informasi akuntansi berguna untuk pembuatan keputusan untuk dapat mencapai kualitas yang relevan dan reliable, maka laporan keuangan perlu diaudit oleh auditor untuk memberikan jaminan kepada pemakai bahwa laporan keuangan tersebut 
telah disusun sesuai dengan kriteria yang ditetapkan, yaitu Standar Akuntansi Keuangan (SAK) Tahun 2015 yang berlaku di Indonesia. Sebagai contoh pada tahun 2004 dan 2010 terjadi kasus akuntansi berskala besar yang sebagian besar terletak pada penyajian laporan keuangan yang berpengaruh terhadap kualitas hasil audit yang didalamnya terdapat kontribusi dari seorang auditor.

Pada tahun 2004, terdapat kasus yang melibatkan Kantor Akuntan Publik (KAP) Drs. Ketut Gunarsa terbukti telah melakukan pelanggaran terhadap Standar Profesional Akuntan Publik (SPAP) dalam pelaksanaan audit atas laporan keuangan Balihai Resort and Spa untuk tahun buku 2004 yang berpotensi berpengaruh signifikan terhadap Laporan Auditor Independen. Oleh karena itu Menteri Keuangan (Menkeu) membekukan izin Akuntan Publik (AP) Drs. Ketut Gunarsa, Pemimpin Rekan dari KAP K. Gunarsa dan I.B Djagera selama 6 bulan.

Kasus yang terjadi pada tahun 2010 yang melibatkan Raden Motor dengan Akuntan Publik yang bernama Biasa Sitepu yang mengaudit perusahaan tersebut. Skandal ini terungkap setelah terjadi kredit macet senilai Rp. 52 Miliar pada Bank BRI Cabang Jambi. Biasa Sitepu terlibat karena telah membuat opini palsu terhadap laporan keuangan milik Raden Motor untuk mendapatkan pinjaman modal dari Bank BRI Cabang Jambi.

Oleh karena itu, auditor harus meningkatkan kinerjanya agar dapat menghasilkan laporan audit yang dapat diandalkan bagi pihak yang membutuhkan. Agar dapat meningkatkan kinerjanya, auditor harus memegang teguh etika profesi yang telah ditetapkan oleh Ikatan Akuntan Indonesia (IAI), agar situasi persaingan yang tidak sehat dapat dihindari. Tanpa adanya etika profesi, maka akuntan tidak akan ada karena fungsi akuntansi adalah penyediaan informasi untuk proses pembuatan keputusan bisnis oleh pelaku bisnis. Gambaran tentang etika profesi seorang auditor tercermin dalam prinsipprinsip etika yang dirumuskan Ikatan Akuntan Publik Indonesia (IAPI) dan dianggap menjadi kode etik perilaku akuntan Indonesia, yaitu tanggung jawab, kepentingan publik, integritas, objektifitas, kompetensi, kerahasiaan dan perilaku professional. Dengan etika profesi yang tinggi maka akan semakin mempengaruhi kualitas hasil audit.

Salah satu bukti bahwa auditor telah melaksanakan dan memegang teguh etika profesi, auditor harus memiliki pengalaman kerja yang cukup dalam melaksanakan audit atas laporan keuangan. Pengalaman kerja auditor dapat diukur dari jenjang jabatan dalam struktur tempat auditor bekerja, tahun pengalaman kerja, keahlian yang dimiliki auditor yang berhubungan dengan audit, serta pelatihan-pelatihan yang pernah diikuti oleh auditor tentang audit.

Pengalaman kerja yang dimiliki auditor akan berkaitan dengan tingkat ketelitian auditor. Semakin berpengalaman seorang auditor maka semakin teliti dalam menemukan kesalahan pada laporan keuangan yang akan disajikan dan semakin peka untuk menemukan kesalahan laporan yang akan dibuat (Prasetyo \& Utama, 2015). Ada tiga faktor dalam pengalaman auditor, diantaranya adalah pelatihan profesi, pendidikan dan lamanya bekerja (Monorey \& Peter, 2008).

Selain memiliki pengalaman kerja, seorang auditor juga harus mempunyai kompetensi dalam melaksanakan audit. Kompetensi auditor merupakan kemampuan seorang auditor untuk mengaplikasikan pengetahuan dan 
pengalaman yang telah dimiliki dalam melakukan audit sehingga auditor dapat melakukan audit dengan teliti, cermat dan objektif. Pengetahuan seorang auditor diukur dari seberapa tinggi pendidikan seorang auditor karena dengan demikian auditor akan mempunyai semakin banyak pengetahuan (pandangan) mengenai audit, sehingga dapat megetahui berbagai masalah secara lebih mendalam, selain itu auditor akan lebih mudah dalam mengikuti perkembangan yang semakin kompleks dalam mendeteksi sebuah kesalahan, seorang auditor harus didukung dengan pengetahuan tentang apa dan bagaimana kesalahan tersebut terjadi (Mabruri \& Winarna, 2010). Terdapat empat faktor dalam kompetensi auditor, yaitu pengetahuan umum yang dimiliki auditor, pengalaman auditor, keterampilan khusus dan tingkat pendidikan atau pelatihan yang telah ditempuh auditor (Sarens \& Abdolmohammadi, 2009).

Selain pengalaman kerja dan kompetensi auditor, integritas merupakan salah satu komponen etika profesi yang harus dimiliki oleh auditor yang dapat berpengaruh terhadap kualitas hasil audit. Integritas merupakan kualitas yang mendasari kepercayaan publik dan merupakan patokan bagi anggota dalam menguji semua keputusannya. Integritas mengharuskan seorang auditor untuk bersikap jujur dan transparan, berani, bijaksana dan bertanggung jawab dalam melaksanakan audit (Kulwadee, 2008).

Dengan integritas yang tinggi, maka auditor dapat meningkatkan kualitas hasil auditnya. Integritas auditor penting karena setiap auditor tentu sangat menjaga nama baiknya. Bertindak jujur, transparan dan bertanggung jawab akan menghasilkan audit yang berkualitas. Hal ini tentu akan mengangkat nama dan kredibilitas auditor tersebut dan menjadi auditor yang berintegritas. Sesuai dengan Prinsip Etika Profesi Ikatan Akuntan Indonesia dalam Sukrisno (2000:2), maka dalam penelitian ini yang dijadikan indikator untuk integritas, yaitu kejujuran auditor, keberanian auditor, sikap bijaksana auditor dan tanggungjawab auditor.

Sedangkan kualitas hasil audit itu sendiri adalah segala kemungkinan dimana auditor pada saat mengaudit laporan keuangan klien dapat menemukan pelanggaran yang terjadi dalam sistem akuntansi klien dan melaporkannya dalam laporan keuangan auditan, dimana dalam melaksanakan tugasnya tersebut auditor berpedoman pada standar auditing dan kode etik akuntan publik yang relevan.

Ikatan Akuntan Indonesia (IAI) menyatakan bahwa audit yang dilakukan auditor dikatakan berkualitas, jika memenuhi standar auditing dan standar pengendalian mutu. Seorang auditor harus mempertahankan kualitas dari laporan auditnya, karena kualitas jasa sangat penting untuk meyakinkan bahwa profesi bertanggung jawab kepada klien, masyarakat umum dan aturan-aturan.

Penelitian ini dilakukan pada KAP yang terdapat di Provinsi Bali. Jumlah KAP yang terdapat di Provinsi Bali yaitu sebanyak 9 KAP dengan jumlah keseluruhan auditor sebanyak 85 orang auditor.

Penelitian ini merupakan pengembangan penelitian yang dilakukan oleh (Kovinna \& Betri, 2014). Perbedaan penelitian ini dengan penelitian sebelumnya ialah terletak pada objek penelitian yang dimana pada penelitian sebelumnya objek penelitian dilakukan di KAP di Kota Palembang, sedangkan objek penelitian ini dilakukan di Provinsi Bali dan penambahan variable yaitu 
integritas auditor, karena auditor yang berintegritas akan bersikap jujur, transparan, berani, bijaksana dan bertanggung jawab dalam melaksanakan audit. Dengan integritas yang tinggi akan memberikan pengaruh terhadap kualitas hasil audit.

Berdasarkan latar belakang masalah, pokok permasalahan yang dapat diangkat dalam penelitian ini adalah, 1) Apakah pengalaman kerja auditor berpengaruh pada kualitas hasil audit di KAP di Kota Denpasar ? 2) Apakah kompetensi auditor berpengaruh pada kualitas hasil audit di KAP di Kota Denpasar ? 3) Apakah integritas auditor berpengaruh pada kualitas hasil audit di KAP di Kota Denpasar?

Tujuan dalam penelitian ini adalah 1) Untuk mengetahui pengaruh pengalaman kerja auditor pada kualitas hasil audit di KAP di Kota Denpasar. 2) Untuk mengetahui pengaruh kompetensi auditor pada kualitas hasil audit di KAP di Kota Denpasar. 3) Untuk mengetahui pengaruh integritas auditor pada kualitas hasil audit di KAP di Kota Denpasar.

Penelitian ini diharapkan dapat digunakan sebagai salah satu hasil studi yang dapat memberikan wawasan, pemahaman serta gambaran mengenai pengalaman kerja, kompetensi dan integritas auditor yang mempengaruhi kualitas hasil audit pada KAP di Kota Denpasar.

Penelitian ini diharapkan dapat digunakan sebagai refrensi KAP dalam meningkatkan dan memaksimalkan tugas auditor dan tanggung jawabnya dalam menghasilkan laporan audit yang berkualitas.

Teori keagenan adalah konsep yang menjelaskan hubungan kontraktual antara prinsipal dan agen, yaitu antara dua atau lebih individu, kelompok atau organisasi. Pihak prinsipal adalah pihak yang mengambil keputusan dan memberikan mandat kepada pihak lain (agen), untuk melakukan semua kegiatan atas nama prinsipal.

Teori keagenan memiliki tiga asumsi, yaitu, 1) asumsi tentang sifat manusia, yaitu sifat manusia yang mengutamakan kepentingan sendiri (self interest), keterbatasan rasionalitas atau daya pikir terhadap persepsi masa depan (bounded rationality), dan cenderung untuk menghindari risiko, 2) asumsi tentang keorganisasian, adalah konflik antar anggota organisasi, efisiensi, dan asimetri informasi yang terjadi antara prinsipal dan agen, dan 3) asumsi tentang informasi, adalah informasi dianggap sebagai barang komoditi yang dapat diperjualbelikan. Berdasarkan ketiga asumsi tersebut manusia akan bertindak oportunistik, yaitu mengutamakan kepentingan pribadi daripada kepentingan organisasi.

Prinsipal ingin mengetahui segala informasi yang terkait dengan investasi atau dananya dalam perusahaan. Hal ini dilakukan dengan meminta laporan pertanggungjawaban pada agen (manajemen). Berdasarkan laporan tersebut principal akan menilai kinerja manajemen, sehingga manajeman cenderung melakukan tindakan yang membuat laporannya kelihatan baik. Untuk mengantisipasi kecurangan yang dilakukan oleh manajemen dalam membuat laporan keuangan yang lebih reliable (dapat dipercaya) diperlukan pengujian. Pengujian ini dilakukan oleh pihak yang independen, yaitu auditor independen (Skinner \& Srinivasan, 2009). 
Pengguna informasi laporan keuangan akan lebih mempercayai informasi yang disediakan oleh auditor yang kredibel. Auditor yang kredibel dapat memberikan informasi yang lebih baik kepada pengguna informasi, karena dapat mengurangi asimetris informasi antara pihak manajemen dengan pihak pemilik. Jadi, teori keagenan untuk membantu auditor sebagai pihak ketiga untuk memahami konflik kepentingan yang dapat muncul antara principal dan agen. Dengan adanya auditor yang independen diharapkan tidak terjadi kecurangan dalam laporan keuangan yang dibuat oleh manajemen. Sekaligus dapat mengevaluasi kinerja agen sehingga akan menghasilkan sistem informasi yang relevan yang berguna bagi investor, kreditor dalam mengambil keputusan rasional untuk investasi (Tan \& Kao, 1999).

Pengalaman kerja merupakan suatu ukuran tentang lama waktu atau masa kerja seorang auditor dalam melakukan audit dan jumlah tugas pemeriksaan yang telah dilakukan. Pengalaman merupakan unsur professional yang penting untuk membangun pengetahuan dan keahlian seorang auditor. Pengalaman bagi seorang auditor merupakan elemen penting dalam menjalankan profesinya selain dari pendidikan. Pengalaman dapat diperoleh melalui pelatihan-pelatihan, supervisi, maupun review terhadap hasil pekerjaan yang diberikan oleh auditor yang lebih berpengalaman.

Pengalaman kerja yang dimiliki oleh auditor dapat meningkatkan kualitas audit. Bahwa adanya pengalaman yang besar dari auditor akan menghasilkan audit yang semakin berkualitas (Carolita \& Rahardjo, 2012). Kemudian hal tersebut mendukung bahwa pengalaman akan mempengaruhi penilaian atau pendapat seseorang. Seorang auditor yang memiliki pengalaman yang besar akan dapat melakukan penilaian dengan baik. Pengalaman kerja audit yang lebih besar secara signifikan dapat meningkatkan kualitas hasil audit laporan keuangan (Candradewi, 2007).

Hasil penelitian ini sejalan dengan penelitian yang dilakukan oleh Juliarsa \& Septiani (2014), dan Dewi (2016) yang menyimpulkan bahwa pengalaman kerja berpengaruh positif terhadap kualitas hasil audit. Berdasarkan penjelasan, dapat dibuat hipotesis sebagai berikut.

$\mathrm{H}_{1}$ : Pengalaman kerja berpengaruh positif terhadap kualitas audit.

Kemungkinan auditor menemukan serta melaporkan pelanggaran pada system akuntansi pada perusahaan sangatlah besar seperti yang telah ditetapkan pada standar akuntansi dan standar audit yang berlaku (Zulkarnain, 2009). Kompetensi auditor menurut Carolita \& Rahardjo (2012) merupakan kemampuan seorang auditor untuk mengaplikasikan pengetahuan dan pengalaman yang telah dimilikinya dalam melakukan audit sehingga auditor dapat melakukan audit dengan teliti, cermat dan obyektif.

Kompetensi yang dibutuhkan oleh seorang auditor, yaitu mutu profesional, pengetahuan umum dan keahlian khusus. Auditor harus memiliki pengetahuan untuk memahami entitas yang diaudit, kemudian auditor harus memiliki kemampuan untuk bekerja sama dalam tim serta kemampuan dalam menganalisa permasalahan. Auditor dikatakan memiliki kemampuan professional apabila dapat memberikan jaminan atau kepastian bahwa teknis dan latar belakang pendidikan para auditor tersebut telah sesuai dengan pemeriksaan yang akan dilaksanakan, juga haruslah memiliki atau mendapatkan 
pengetahuan, kecakapan dari berbagai disiplin ilmu yang dibutuhkan untuk melaksanakan tanggung jawab pemeriksaan auditor harus mencerminkan keahlian dan ketelitian profesional.

Hasil penelitian ini sejalan dengan penelitian yang dilakukan oleh Ilmiyati \& Suhardjo (2012), dan Dewi (2016) yang menyimpulkan bahwa kompetensi berpengaruh positif terhadap kualitas hasil audit. Berdasarkan penjelasan, dapat dibuat hipotesis sebagai berikut.

$\mathrm{H}_{2}$ : Kompetensi berpengaruh positif terhadap kualitas audit.

Integritas adalah sesuatu elemen karakter yang mendasari timbulnya pengakuan profesional. Integritas merupakan kualitas yang melandasi kepercayaan publik dan merupakan patokan (benchmark) bagi anggota dalam menguji semua keputusan yang diambilnya. Integritas mengharuskan seorang anggota untuk, bersikap jujur dan berterus terang tanpa harus mengorbankan rahasia penerima jasa. Integritas yang tinggi yang dimiliki oleh auditor dapat mempengaruhi kualitas audit.

Untuk memelihara dan meningkatkan kepercayaan publik, setiap auditor harus memenuhi tanggung jawab profesionalnya dengan integritas setinggi mungkin. Dengan integritas yang tinggi, maka auditor dapat meningkatkan kualitas hasil pemeriksaannya (Baotham, 2007).

Hasil penelitian ini sejalan dengan penelitian yang dilakukan oleh Fitriani \& Hidayat (2013), dan Sari (2014) yang menyimpulkan bahwa integritas auditor berpengaruh positif terhadap kualitas hasil audit.Berdasarkan penjelasan, dapat dibuat hipotesis sebagai berikut.

$\mathrm{H}_{3}$ : Integritas berpengaruh positif terhadap kualitas audit.

\section{METODE PENELITIAN}

Untuk memenuhi tuntutan akuntabilitas publik dan good governance, diperlukan adanya pemeriksaan. Dalam melasanakan proses pemeriksaan, auditor membutuhkan pengalaman kerja, kompetensi dan integritas yang tinggi. Karena degan hal itu auditor menjadi lebih mampu memahami kondisi keuangan dan laporan keuangan kliennya dan akan menghasilkan audit yang berkualitas.

Auditor yang berpengalaman akan memiliki lebih banyak pengetahuan dibandingkan yang belum berpengalaman. Auditor yang tidak berpengalaman akan melakukan atribusi kesalahan yang lebih tinggi dibandingkan dengan auditor yang lebih berpengalaman.

Persyaratan lain yang harus dimiliki oleh seorang auditor adalah keahlian. Kompetensi merupakan kualifikasi yang dibutuhkan oleh auditor untuk melaksanakan audit dengan benar. Kompetensi yang dibutuhkan oleh seorang auditor, yaitu mutu professional, pengetahuan umum dan keahlian khusus.(Demir, 2011). Dengan kompetensi yang memadai yang dimiliki oleh auditor, menjadikan auditor semakin peka dan dapat mendeteksi dengan cepat dan tepat ada tidaknya kecurangan serta trik-trik rekayasa (Agustia, 2011).

Hal itu dapat mempengaruhi kualitas hasil audit yang dihasilkan oleh auditor. Untuk memelihara dan meningkatkan kepercayaan publik, setiap auditor harus memenuhi tanggungjawab profesionalnya dengan integritas setinggi mungkin. Seorang auditor yang mempertahankan integritas akan bertindak jujur dan tegas dalam mempertimbangkan fakta, terlepas dari 
kepentingan pribadi (Bamber \& M, 2002). Dengan tingginya integritas yang dimiliki auditor dalam menyelesaikan proses audit, akan menghasilkan kinerja yang baik yang dalam hal ini yaitu audit yang berkualitas. Penelitian ini dimaksudkan untuk mengukur pengaruh pengalaman kerja, komepetensi dan integritas auditor terhadap kualitas hasil audit.

Penelitian ini dilakukan di KAP yang terdapat di Provinsi Bali. Pemilihan Provinsi Bali sebagai lokasi penelitian didasarkan pada pertimbangan bahwa masih diperlukan peningkatan kualitas audit di KAP di Provinsi Bali.

Objek penelitian pada penelitian ini adalah kualitas audit pada KAP yang terdapat di Provinsi Bali, khususnya mengenai pengaruh dari faktor pengalaman kerja, kompetensi dan integritas pada kualitas audit. Variabel terikat dalam penelitian ini adalah kualitas hasil audit. Dalam penelitian ini yang menjadi variabel bebas adalah mengenai pengaruh dari faktor pengalaman kerja, kompetensi, dan integritas auditor.

Pengalaman kerja merupakan suatu ukuran tentang lama waktu atau masa kerja seorang auditor yang bekerja pada KAP yang terdapat di Provinsi Bali dalam melakukan audit dan jumlah tugas yang telah dilakukan. Apabila auditor sudah memiliki pengalaman bekerja sebagai auditor dalam melakukan general audit, maka akan memberikan penjelasan yang lebih masuk akal dan memiliki cara berpikir yang luas dan terinci dibandingkan dengan yang belum memiliki banyak pengalaman. Pengalaman auditor akan semakin berkembang dengan bertambahnya pengalaman audit, mengikuti pelatihan dan penggunaan standar auditing. Indikator pada pengalaman auditor disini ialah : 1 . Lamanya bekerja dan 2. Banyaknya tugas audit yang telah dilakukan.

Kompetensi auditor adalah kualifikasi yang dibutuhkan oleh auditor yang bekerja pada KAP yang terdapat di Provinsi Bali untuk melaksanakan audit dengan benar, kompetensi yang dibutuhkan oleh seorang auditor, yaitu mutu profesional, pengetahuan umum dan keahlian khusus untuk memperoleh kompetensi tersebut dibutuhkan pendidikan dan pelatihan bagi auditor. Kompetensi berkaitan dengan keahlian professional yang dimiliki oleh auditor sebagai hasil dari pendidikan formal, ujian profesional maupun keikutsertaan dalam pelatihan, seminar, simposum.

Kompetensi diperlukan agar auditor dapat mendeteksi dengan cepat dan tepat ada tidaknya kecurangan serta trik-trik rekayasa yang dilakukan dengan melakukan kecurangan tersebut karena keahlian yang dimilikinya dapat menjadikannya lebih sensitive (peka) terhadap tindak kecurangan. Indikator pada kompetensi disini ialah, 1. Mutu personal, 2. Pengetahuan umum, dan 3. Keahlian khusus.

Integritas adalah sesuatu elemen karakter yang mendasari timbulnya pengakuan profesional. Integritas merupakan kualitas yang melandasi kepercayaan publik dan merupakan patokan bagi auditor yang bekerja pada KAP yang terdapat di Provinsi Bali dalam menguji semua keputusan yang diambilnya. Integritas mengharuskan seorang auditor untuk bersikap jujur dan transparan, berani, bijaksana dan bertanggung jawab dalam melaksanakan audit. untuk memelihara dan meningkatkan kepercayaan public, setiap auditor harus memenuhi tanggung jawab profesionalnya dengan integritas setinggi mungkin. Dengan integritas yang tinggi, maka auditor dapat meningkatkan kualitas hasil 
pemeriksaannya. Indikator pada integritas disini ialah, 1. Kejujuran auditor, 2. Keberanian auditor, 3. Sikap bijaksana auditor dan 4. Tanggung Jawab Auditor.

Kualitas hasil audit merupakan fungsi jaminan dimana kualitas tersebut akan digunakan untuk membandingkan kondisi yang sebenarnya dengan kondisi yang seharusnya (Sari,2014). Berdasarkan Standar Profesional Akuntan Publik (SPAP) IAI, (2017) audit yang dilaksanakan oleh auditor yang bekerja pada KAP yang terdapat di Provinsi Bali dapat dikatakan berkualitas jika memenuhi ketentuan atau standar auditing yang berlaku umum (generally accepted auditing standars) dan standar pengendalian mutu. Indikator kualitas hasil audit disini ialah, 1 . Kesesuaian audit dengan standar audit dan 2. Kualitas laporan hasil audit.

Populasi pada penelitian ini adalah seluruh auditor yang bekerja pada KAP di Kota Denpasar. Metode penentuan sampel yang digunakan dalam penelitian ini adalah purposive sampling yaitu teknik penentuan sampel dengan pertimbangan tertentu. Jumlah sampel dapat dilihat pada Tabel 1.

Tabel 1. Jumlah Auditor di KAP Kota Denpasar

\begin{tabular}{llc}
\hline No. & \multicolumn{1}{c}{ Nama Kantor Akuntan Publik } & Jumlah Auditor \\
\hline 1. & KAP Arnaya \& Darmayasa & 6 \\
2. & KAP Budhananda Munidewi & 7 \\
3. & KAP I Wayan Ramantha & 4 \\
4. & KAP Johan Malonda Mustika \& Rekan (Cabang) & 10 \\
5. & KAP K. Gunarsa & 10 \\
6. & KAP Drs. Ketut Budiartha, M.Si & 8 \\
7. & KAP Drs. Ketut Muliartha Rm \& Rekan & 10 \\
8. & KAP Drs. Sri Marmo Djogosarkoro \& Rekan & 20 \\
9. & KAP Drs. Wayan Sunasdyana & 10 \\
\hline
\end{tabular}

Sumber: KAP Kota Denpasar, 2019

Data kuantitatif yang digunakan dalam penelitian ini adalah jumlah KAP yang ada di Kota Denpasar, jumlah auitor yang bekerja di KAP di Kota Denpasar dan hasil skor jawaban kuisioner dari responden pada KAP di Kota Denpasar. Data kualitatif dalam penelitian ini ialah berupa informasi mengenai KAP di Kota Denpasar.

Sumber data yang digunakan dalam penelitian ini adalah data primer. Data primer adalah data yang diperoleh secara langsung dari sumber aslinya. Data primer biasanya diperoleh dari survey dilapangan yang menggunakan semua metode pengumpulan data. Teknik pengumpulan data yang digunakan dalam penelitian ini adalah dengan menyebarkan kuisioner pada KAP yang ada di Kota Denpasar untuk mengetahui pengaruh pengalaman kerja, kompetensi dan integritas auditor terhadap kualitas hasil audit.

\section{HASIL DAN PEMBAHASAN}

Kantor Akuntan Publik yang berada di Provinsi Bali berjumlah 9 KAP. Seluruh KAP ini terdapat di Kota Denpasar. Kota Denpasar merupakan ibukota dari provinsi Bali. Kota Denpasar terbagi menjadi 4 kecamatan, yaitu Denpasar Utara, Denpasar Timur, Denpasar Selatan, dan Denpasar Barat. Kota Denpasar merupakan pusat pemerintahan, ekonomi, industri, serta pendidikan di Provinsi Bali. 
Hasil Uji validitas menunjukkan bahwa setiap item pertanyaan pada kuisioner memiliki nilai r-hitung yang lebih besar daripada nilai r-tabel yaitu 0,2441 sehingga 42 pertanyaan dalam kuisioner yang digunakan dinyatakan valid.

Uji reliabilitas menunjukkan nilai Cronbach's Alpha sebesar 0,965. Nilai Cronbach's Alpha yang dihasilkan lebih besar dari 0,6 dan cukup mendekati 1 sehingga dapat disimpulkan bahwa kuisioner yang digunakan sudah reliabel. Karena kuisioner sudah dinyatakan valid dan reliabel, maka kuisioner dapat digunakan sebagai alat ukur dan analisia lebih lanjut.

Hasil uji Kolmogorov-Smirnov menunjukkan bahwa nilai Asymp. Sig. (2tailed) sebesar 0.483. Nilai ini lebih besar dari signifikan 0,05 sehingga dapat disimpulkan bahwa data mengikuti sebaran normal. Oleh karena itu asumsi normalitas pada regresi telah terpenuhi.

Uji multikoleniaritas menunjukkan bahwa untuk semua variabel independen Pengalaman Kerja, Kompetensi dan Integritas Auditor memiliki nilai VIF yang dihasilkan kurang dari 10 dan nilai tolerance $>10 \%$ sehingga dapat disimpulkan bahwa tidak terjadi korelasi ganda (multikolinieritas) antar variabel independen. Oleh karena itu asumsi multikolinieritas telah terpenuhi.

Tabel 2. Hasil Uji Heterokedasitas

\begin{tabular}{|c|c|c|c|c|c|c|}
\hline & Model & Sum of Squares & $\mathrm{df}$ & Mean Square & $\mathrm{F}$ & Sig. \\
\hline \multirow{3}{*}{1} & Regression & 0.000 & 3 & 0.000 & 0.000 & $1.000^{\mathrm{b}}$ \\
\hline & Residual & 0.373 & 61 & 0.006 & & \\
\hline & Total & 0.373 & 64 & & & \\
\hline
\end{tabular}

Sumber: Data Penelitian, 2019

Berdasarkan Tabel 2, apat dilihat bahwa hasil regresi antara absolut residual dengan variabel bebas tidak signifikan atau nilai signifikan sebesar 1.000 di atas 0.05 sehinga tidak terjadi heterokedasitas dan asumsi regresi terpenuhi.

Tabel 3. Hasil Uji Parsial Heterokedasitas

\begin{tabular}{llrrrr}
\hline \multirow{2}{*}{ Model } & \multicolumn{2}{c}{ Unstandardized Coefficients } & & \multirow{2}{*}{ Sig. } \\
\cline { 2 - 3 } & \multicolumn{2}{c}{ B } & Std. Error & & \\
\hline \multirow{2}{*}{1} & (Constant) & $-4.582 \mathrm{E}-016$ & 0.095 & 0.000 & 1.000 \\
& Pengalaman Kerja & 0.000 & 0.086 & 0.000 & 1.000 \\
& Kompetensi & 0.000 & 0.062 & 0.000 & 1.000 \\
& Integritas Auditor & 0.000 & 0.103 & 0.000 & 1.000 \\
\hline
\end{tabular}

Sumber: Data Penelitian, 2019

Jika model tersebut diuji secara parsial menunjukkan bahwa semua variabel bebas yang digunakan tidak signifikan pada level 0,05 terhadap absolut residual sehingga dapat disimpulkan bahwa tidak terjadi heterokedasitas.

Nilai koefisien $X_{1}$ (Pengalaman Kerja) sebesar -0.210 maka artinya apabila nilai $X_{1}$ (Pengalaman Kerja) naik satu satuan maka nilai Kualitas Hasil Audit akan turun sebesar 0.210 satuan jika nilai $\mathrm{X}_{2}$ (Kompetensi) dan $\mathrm{X}_{3}$ (Integritas Auditor) dipertahankan konstan.

Nilai koefisien $\mathrm{X}_{2}$ (Kompetensi) sebesar 0.257 maka artinya apabila nilai $\mathrm{X}_{2}$ (Kompetensi) naik satu satuan maka nilai Kualitas Hasil Audit akan naik sebesar 0.257 satuan jika nilai $X_{1}$ (Pengalaman Kerja) dan $X_{3}$ (Integritas Auditor) dipertahankan konstan. 
Tabel 4. Hasil Uji Regresi Linier Berganda

\begin{tabular}{|c|c|c|c|c|c|c|}
\hline \multicolumn{2}{|c|}{ Model } & \multicolumn{2}{|c|}{$\begin{array}{l}\text { Unstandardized } \\
\text { Coefficients }\end{array}$} & \multirow{2}{*}{$\begin{array}{c}\text { Standardized } \\
\text { Coefficients }\end{array}$} & \multirow[t]{2}{*}{$\mathrm{t}$} & \multirow[t]{2}{*}{ Sig. } \\
\hline & & B & Std. Error & & & \\
\hline \multirow{4}{*}{1} & (Constant) & 0.139 & 0.095 & & 1.456 & 0.151 \\
\hline & $\begin{array}{l}\text { Pengalaman } \\
\text { Kerja }\end{array}$ & -0.210 & 0.086 & -0.218 & -2.453 & 0.017 \\
\hline & Kompetensi & 0.257 & 0.062 & 0.347 & 4.153 & 0.000 \\
\hline & $\begin{array}{l}\text { Integritas } \\
\text { Auditor }\end{array}$ & 0.857 & 0.103 & 0.855 & 8.345 & 0.000 \\
\hline
\end{tabular}

Sumber: Data Penelitian, 2019

Nilai koefisien $\mathrm{X}_{3}$ (Integritas Auditor) sebesar 0.857 maka artinya apabila nilai $X_{3}$ (Integritas Auditor) naik satu satuan maka nilai Kualitas Hasil Audit akan naik sebesar 0.857 satuan jika $X_{1}$ (Pengalaman Kerja) dan nilai $X_{2}$ (Kompetensi) dipertahankan konstan.

Analisis regresi yang digunakan adalah analisis regresi berganda sehingga koefisien determinasi yang digunakan adalah Adjusted $\mathrm{R}$ square (koefisien determinasi terkoreksi). Nilai koefisien yang diperoleh adalah sebesar 0.963.

Nilai determinasinya menjadi $0.963 \times 100 \%=96.3 \%$. Hal ini mengindikasikan bahwa Kualitas Hasil Audit dijelaskan 96.3\% oleh variabel Pengalaman Kerja, Kompetensi dan Integritas Auditor, sisanya dijelaskan oleh variabel lain yang tidak dimasukkan ke dalam model.

Tabel 5. Hasil Uji Kelayakan Model (Uji F)

\begin{tabular}{|c|c|c|c|c|c|c|}
\hline & Model & Sum of Squares & $\mathrm{df}$ & Mean Square & $\mathrm{F}$ & Sig. \\
\hline \multirow{3}{*}{1} & Regression & 10.304 & 3 & 3.435 & 561.654 & $0.000^{\mathrm{b}}$ \\
\hline & Residual & 0.373 & 61 & 0.006 & & \\
\hline & Total & 10.678 & 64 & & & \\
\hline
\end{tabular}

Sumber: Data Penelitian, 2019

Pada Tabel 5, dapat dilihat nilai signifikan sebesar 0,000 atau $<0,05$ maka menunjukkan bahwa variabel independen yang digunakan yaitu variabel Pengalaman Kerja, Kompetensi dan Integritas Auditor berpengaruh signifikan secara simultan atau model dikatakan layak dalam regresi berganda.

Tabel 6. Hasil Uji Hipotesis (Uji t)

\begin{tabular}{llrrrr}
\hline \multirow{2}{*}{ Model } & \multicolumn{2}{c}{$\begin{array}{c}\text { Unstandardized } \\
\text { Coefficients }\end{array}$} & $\begin{array}{c}\text { Standardized } \\
\text { Coefficients }\end{array}$ & $\mathrm{t}$ & Sig. \\
\cline { 2 - 7 } & $\mathrm{B}$ & Std. Error & \multicolumn{1}{c}{ Beta } & & \\
\hline (Constant) & 0.139 & 0.095 & & 1.456 & 0.151 \\
$\begin{array}{l}\text { Pengalaman } \\
\text { Kerja }\end{array}$ & -0.210 & 0.086 & -0.218 & -2.453 & 0.017 \\
Kompetensi & 0.257 & 0.062 & 0.347 & 4.153 & 0.000 \\
$\begin{array}{l}\text { Integritas } \\
\text { Auditor }\end{array}$ & 0.857 & 0.103 & 0.855 & 8.345 & 0.000 \\
\hline
\end{tabular}

Sumber: Data Penelitian, 2019

Setelah diuji secara parsial dengan menggunakan uji $t$, diperoleh nilai sig. untuk variabel Pengalaman Kerja $\left(X_{1}\right)$ yaitu sebesar 0.017. Nilai sig. ini lebih kecil dari 0.05 sehingga dapat disimpulkan bahwa variabel Pengalaman Kerja $\left(X_{1}\right)$ berpengaruh signifikan terhadap Kualitas Hasil Audit. 
Setelah diuji secara parsial dengan menggunakan uji t, diperoleh nilai sig. untuk variabel Kompetensi $\left(\mathrm{X}_{2}\right)$ yaitu sebesar 0.000. Nilai sig. ini lebih kecil dari 0.05 sehingga dapat disimpulkan bahwa variabel Kompetensi $\left(\mathrm{X}_{2}\right)$ berpengaruh signifikan terhadap Kualitas Hasil Audit.

Setelah diuji secara parsial dengan menggunakan uji $t$, diperoleh nilai sig. untuk variabel Integritas Auditor $\left(X_{3}\right)$ yaitu sebesar 0.000. Nilai sig. ini lebih kecil dari 0.05 sehingga dapat disimpulkan bahwa variabel Integritas Auditor $\left(X_{3}\right)$ berpengaruh signifikan terhadap Kualitas Hasil Audit.

Berdasarkan pembahasan yang telah diuraikan terdapat implikasi praktis bahwa KAP harus membagi tugas-tugas yang ada, dan tidak membebankannya hanya pada auditor yang berpengalaman karena berpotensi terjadinya penumpukan tugas. Hal ini juga akan lebih memaksimalkan kerja auditor sehingga dihasilkan laporan yang lebih relevan dan reliabel

Penelitian ini juga memberikan implikasi teoritis bahwa auditing dapat menjelaskan pengaruh pengalaman kerja, kompetensi, dan integritas auditor pada kualitas hasil audit KAP di Kota Denpasar. Hasil uji dalam penelitian ini menemukan bahwa pengalaman kerja berpengaruh negatif pada kualitas hasil audit, sedangkan kompetensi dan integritas auditor berpengaruh positif pada kualitas hasil audit. Berdasarkan hasil tersebut kualitas hasil audit KAP di Kota Denpasar didasarkan pada pengalaman kerja, komptensi, serta integritas auditor.

\section{SIMPULAN}

Berdasarkan hasil analisis dan pembahasan mengenai Bagaimana Pengaruh Pengalaman Kerja, Kompetensi dan Integritas Auditor Terhadap Kualitas Hasil Audit Pada Kantor KAP, maka dapat ditarik kesimpulan yaitu Pengalaman Kerja Berpengaruh Negatif pada Kualitas Hasil Audit di KAP di Kota Denpasar, Kompetensi Berpengaruh Positif pada Kualitas Hasil Audit di KAP di Kota Denpasar dan Integritas Auditor Berpengaruh Positif pada Kualitas Hasil Audit di KAP di Kota Denpasar.

Saran yang dapat diberikan berkaitan dengan hasil analisis dan pembahasan dalam penelitian ini adalah KAP memperhatikan semua variabel Pengalaman Kerja, Kompetensi dan Integritas Auditor karena variabel tersebut berpengaruh signifikan terhadap Kualitas Hasil Audit. Terutama variabel integritas auditor karena memiliki nilai signifikan paling besar dimana semakin tinggi Integritas seorang auditor maka semakin baik kualitas hasil audit mereka.

\section{REFERENSI}

Agustia, D. (2011). The Influence Of Auditor's Profesionalism to Turnover Intentions, An Empirical Study On Accounting Firm In Java And Bali, Indonesia". Journal of Economics and Engineering. Journal Accounting Department, 2(1), 1-12.

Bamber, E. M., \& M, I. V. (2002). Big 5 Auditors' Professional And Organizational Identification: Consistency Or Conflict? Journal of Practice $\mathcal{E}$ Theory, 3(1), 110.

Baotham, S. (2007). Effects of Professionalism on Audit Quality and Self Image of CPAs in Thailand. International Journal of Business Strategy, 7(2), 1-20. 
Candradewi, A. A. S. P. M. (2007). Pengaruh tingkat pendidikan, Hirarki Jabatan, dan Pengalaman Kerja terhadap Profesionalisme Auditor Kantor Akuntan Publik di Bali. Jurnal Akuntansi, 1(1), 1-20.

Carolita, K. M., \& Rahardjo, N. S. (2012). Pengaruh Pengalaman Kerja, Independensi Objektifitas, Integritas, Kompetensi, dan Komitmen Organisasi Hasil Audit. Diponegoro Journal Of Accounting, 1(1), 1-11.

D'Arcy, B., Haugen, S., \& Mattson. (2005). Continuing Ethics Education is Critical to Improving Professional Conduct of Auditors. Journal of Legal, Ethical, and Regulatory Issues, 1(1), 1-15.

Demir, T. (2011). Auditing. International Journal of Public Administration, 1(1), 1-30.

Dewi, A. C. (2016). Pengaruh Pengalaman Kerja, Kompetensi, dan Independensi Terhadap Kualitas Audit dengan Etika Auditor Sebagai Variabel Moderasi. Jurnal Fakultas Ekonomi Universitas Negeri Yogyakarta, 1(1), 1-12.

Feney, A. (2017). Faktor-faktor yang Mempengaruhi Audit Judgement Pada Kantor Akuntan Publik di Kota Denpasar. Jurnal Akuntansi \& Auditing, 1(1), 1-20.

Fitriani, \& Hidayat, Y. L. (2013). Pengaruh Objektivitas dan Integritas Auditor Internal Terhadap Kualitas Audit. Jurnal Fakultas Ekonomi, Universitas Pendidikan Indonesia, 1(1), 1-20.

Hassink, W. H. J., \& Russo, G. (2010). The Glass Door: The Gender Composition of Newly-Hired Workers Across Hierarchical Job Levels. Journal Accounting, 10(1), 1-13.

Ilmiyati, F., \& Suhardjo, Y. (2012). Pengaruh Akuntabilitas dan Kompetensi Auditor Terhadap Kualitas Audit. Jurnal Akuntansi Dan Keuangan, 1(1), 1-10.

Juliarsa, \& Septiani, P. (2014). Pengaruh Independensi, Profesionalisme, Tingkat Pendidikan, Etika Profesi, Pengalaman, dan Kepuasan Kerja Auditor Pada Kualitas Audit Kantor Akuntan Publik di Bali. E-Jurnal Akuntansi Universitas Udayana, 1(1), 1-10.

Kovinna, F., \& Betri. (2014). Pengaruh Independensi, Pengalaman Kerja, Kompetensi, dan Etika Auditor Terhadap Kualitas Audit (Studi Kasus pada Kantor Akuntan Publik di kota Palembang). Jurnal STIE MDP, 1(1), 1-30.

Kulwadee, S. L.-U. (2008). Relationship Quality, Professionalism, And Audit Quality: An Empirical Study Of Auditors In Thailand. International Journal Of Business Research, 8(4), 1-12.

Mabruri, \& Winarna. (2010). Analisis Faktor-Faktor Yang Mempengaruhi Kualitas Hasil Audit di Lingkungan Pemerintah Daerah. Jurnal Akuntansi \& Auditing, 2(1), 1-20.

Monorey, R. A., \& Peter. (2008). Industry Versus Task-Based Experience Auditor Perfomance. Journal of Accounting Research, 1(1), 12.

Prasetyo, \& Utama, K. (2015). Pengaruh Independensi, Etika Profesi, Pengalaman Kerja dan Tingkat Pendidikan Auditor Pada Kualitas Audit. E-Jurnal Akuntansi Universitas Udayana, 1(1), 1-25.

Pratistha, \& Widhiyani, N. L. S. (2014). Pengaruh Independensi Auditor dan Besaran Fee Audit terhadap Kualitas Proses Audit. Jurnal Akuntansi Universitas Udayana, 6(3), 419-428.

Sarens, G., \& Abdolmohammadi, M. (2009). Cultural Dimension And Professionalism and Uniformity of Internal Auditing Practice. Journal 
Accounting Department, 1(1), 23.

Sari, Z. (2014). Analisis Faktor-Faktor Penentu Kualitas Audit yang Dirasakan dan Kepuasan Auditee di Pemerintahan Daerah. Jurnal Akuntansi Universitas Diponegoro, 12(1), 1-12.

Skinner, D. J., \& Srinivasan, S. (2009). Audit Quality and Auditor Reputation: Evidence from Japan. Journal of Accounting \& Management, 1(1), 12.

Sukrisno, A. (2000). Auditing. Edisi ke-3. Jakarta: Lembaga Penerbit Fakultas Ekonomi Universitas Indonesia.

Tan, H.-T., \& Kao, A. (1999). Accountability Effects on Auditors' Performance: Influence of Knowledge, Problem-Solving Ability, and Task Complexity. Journal of Accounting Research, 3(7), 1-20.

Zulkarnain, M. S. (2009). Audit Committee and Auditor Independence: The Bankers' Perception. International Journal of Economics and Management, 3(2), $317-331$. 